九州大学学術情報リポジトリ

Kyushu University Institutional Repository

Ecological Studies on Formica yessensis Forel, with Special Reference to Its Effectiveness as a Biological Control Agent of the Pine Caterpillar Moth in Korea : V. Usefulness of Formica yessensis Forel

Kim, Chang Hyo

Division of Insect Natural Enemies, Institute of Biological Control, Faculty of Agriculture, Kyushu University

Murakami, Yozo

Division of Insect Natural Enemies, Institute of Biological Control, Faculty of Agriculture, Kyushu University

https://doi.org/10.5109/23779

出版情報 : 九州大学大学院農学研究院紀要. $28(2 / 3)$ ，pp.71-82，1983-12. Kyushu University バージョン：

権利関係 : 


\title{
Ecological Studies on Formica yessensis Forel, with Special Reference to Its Effectiveness as a Biological Control Agent of the Pine Caterpillar Moth in Korea
}

\section{Usefulness of Formica yessensis Forel*}

\author{
Chang Hyo Kim** and Yôzô Murakami \\ Division of Insect Natural Enemies, Institute of Biological Control, \\ Faculty of Agriculture, Kyushu University 46-13, Fukuoka 812
}

(Received August 22, 1983)

\begin{abstract}
Formica yessensis is a highly polyphagous predator with a broad spectrum of prey range, i.e., live and dead lepidopterous larvae, coleopterous adults and larvae, hemipterous adults as well as honeydew secreted by aphids. The results of experiments for examining the effect of predation by the ant with the physical check method revealed that the ant is extremely effective in controlling the younger larvae of the pine caterpillar moth, Dendrolimus spectabilis. The ant hunts in one of two ways. The first is a direct attack by worker ants on a twig. The second is hunting by numerous workers on the ground, where caterpillars have dropped to escape from the attack by ants on the twigs. In Korea this ant maintains a very high population density with supercolonies including a number of colonial nests in red pine forests. The predaceous activities of the ant are not density-dependent. When the pine caterpillar is scarce, the ant can maintain its population by feeding on the honeydew of aphids which are not a serious pest of red pine trees. The period of activity of the ant is as long as 200 days per year. These are outstanding characters possessed by the ant, which makes it as an effective biological control agent against the pine caterpillar moth. In addition to its role as an effective predator, the ant may also play an important role in soil improvement and plant enrichment. Therefore, the preservation of this ant species in natural habitats, and the transplantation of its colonies to non-inhabited forests should be recommended.
\end{abstract}

\section{INTRODUCTION}

Formica (Formica) yessensis Forel occurs throughout all the regions of Korea except Jeju-Do and has a large supercolony consisting of many colonial nests in the red pine forests in Korea. The number of workers attained approximately 100,000 per nest, and number of the nests almost 1,000 in a census stand of approximately 2 ha wide (Kim and Murakami, 1980 a, b, 1981 a). These ants must consume an enormous amount of diets in order to maintain their full nest population. It should be supposed that the ant have become

* Presented at the XVI International Congress of Entomology, Kyoto August 3-9, 1980.

** Present address: College of Agriculture, Gyeongsang National University, Jinju 620, Korea. 
possible by developing an omnivorous habit rather than polyphagous, feeding on nector, sap, aphid honeydew, live and dead insects and earthworms, etc.

For many years an active controversy has existed among European entomologists on the pros and cons of red wood ants (Formica rufa group) as the biological control agents (Adlung, 1966; Finnegan, 1974). Some of the main criticisms have been (1) that ants do not hunt many live prey, but simply scavenge already died or dying insects; (2) that they destroy not only harmful insects, but beneficial insects as well; (3) that by feeding on honeydew, and thereby protecting aphids, they are indirectly responsible for aphid damage to plants (Finnegan, 1974). A list of the normal diet of Formica rufa Linnaeus was given by Wellenstein (1952), i.e., $62 \%$ aphid honeydew, 33\% insects (31.3\% unimportant and beneficial insects, and $1.7 \%$ harmful insects), $4.5 \%$ tree sap, $0.3 \%$ mushrooms and carrion, and $0.2 \%$ seeds. Because of the relatively low percentage of harmful insects in the ant diet, several authors have questioned the value of Formica species as the biological control agents (Adlung, 1966). Among European $F$. rufa group some species are valuable as predators but others are less useful. Adlung (1966) has stated that Formica polyctena (Foerster), a polygynous ant, is the most valuable, and Formica lugubris Zett. and Formica aquilonia Yarrow are useful in subalpine forests. While, the oligogynous form of $F$. rufa is less active as a predator and the monogynous form of the ant is rather unimportant as a biological control agent.

As the final report on the ecological studies on $F$. yessensis in Korea, the present paper deals with the diet of the ant and experiments for evaluating its effectiveness by the physical check method conducted by the senior author, and also concerns the discussion of the usefulness of the ant as a biological control agent to the pine caterpillar moth, Dendrolimus spectabilis Butler in Korea.

\section{METHODS}

The kind of diets preyed by $F$. yessensis was examined by nest excavations and field observations in a red pine stand at Jinseung, Jinyang-gun, Gyeongsang-Nam-Do, Korea from 1972 to 1977.

In order to examine the effect of predation by the ant, two experiments were conducted by the physical check method in the same stand as above at Jinseung in 1972. In both experiments twelve small trees (1.5-Z. Om high) were sampled and classified into three treatments and a control (three trees for each). Treatment $A$ means uncaged trees with an ant nest at their base. Here the ants and other natural enemies were free to attack the larvae of the pine caterpillar moth at will. Treatment B means trees with an ant nest at their base but in cages of organdie. Here the ants were free to attack the caterpillar but other natural enemies were excluded. Treatment $C$ means organdie-caged trees without ant nests at their base and treated with sticky flypaper on the trunk to exclude the ant and other natural enemies. 
Control trees were uncaged trees but without ant nests at their base.

The first experiment was conducted from May 8 to 29 and the second one from August 25 to September 8. In the experiment conducted in May, 50 posthibernating mature larvae of the pine caterpillar moth were placed on each experiment tree. In the second experiment conducted in August-September, 50 first to third instar larvae were placed on each experiment tree. The number of living larvae on these experiment trees was counted with threeday interval in the first experiment, whereas with two-day interval in the second one.

\section{RESULTS}

\section{Diets of $F$. yessensis}

Eleven species of insects were found from nests of the ant, i.e., lepidopterous larvae, coleopterous adults and larvae, and hemipterous adults (Table 1). Among them, larvae of $\mathbf{D}$. spectabilis was only species observed being attacked by the ant in the field. The ant hunts in one of two ways. The first is a direct attack by the numerous worker ants on a twig. The second is hunting by numerous workers on the ground, where the caterpillar has dropped to escape from the attack by ants on the twigs. Other than the pine caterpillar moth, scarabaeids and chrysomelids were observed to be important prey of the ant.

Table 1. A list of prey hunted by F. yessensis which were observed in a red pine stand at Jinseung, Gyeongsang-Nam-Do, Korea in 1972-1977.

\begin{tabular}{cc}
\hline \multicolumn{1}{c}{ Prey species } & Prey stage \\
\hline Lepidoptera & \\
Dendrolimus spectabilis Butler & Larva \\
Archippus oporana similis Butler & Larva \\
Coleoptera & \\
Episomus turnitus Gyllenhal & Adult \\
Apodenus jekelii Roelofs & Adult \\
Agelastica coerule Baly & Adult, larva \\
Chrysomela populi Linnaeus & Adult, larva \\
Epicauta chinensis Motschulsky & Adult \\
Lachnostema morosa Waterhouse & Adult \\
L. kiotonensis Brenske & Adult \\
Heptophylla picea Motschulsky & Adult \\
Hemiptera & \\
Velinus nodipes Uhler & Adult \\
\hline
\end{tabular}

Another important diet of the ant was honeydew secreted by a lachnid aphid, Cinara piniformosana Takahashi.

Experiments for evaluating the effectiveness of the ant

The result of the experiments for the effect of predation by the physical check method was given in Figs. 1 and 2 .

In the experiment of the effect on post-hibernating mature larvae, the 


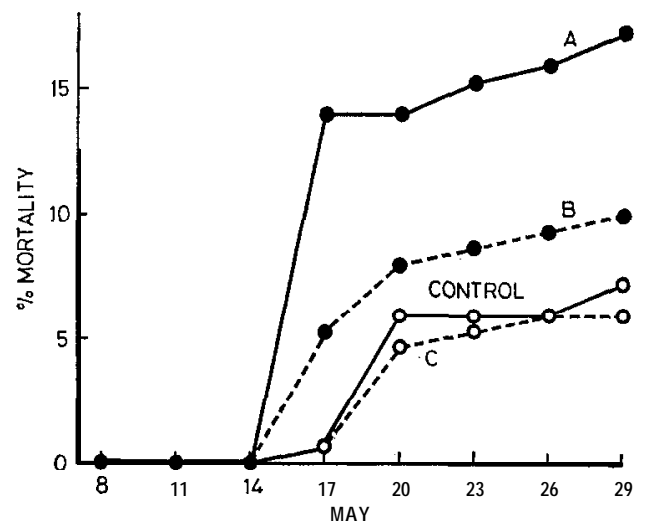

Fig. 1. The mortality of post-hibernating mature larvae of D. spectabilis in an experiment of predation of $F$. yessensis. Treatment A: uncaged trees with an ant nest at their base; treatment B: caged trees with an ant nest at their base; treatment $C$ : caged trees without ant nests at their base and treated with sticky flypaper on the trunk; control: uncaged trees whithout ant nests at their base.

mortality attained only $17.3 \%$, even 21 days after treatment A. There is less difference in mortality between treatments B (affected by the ant only) and $\mathrm{C}$ (excluded the act of the ant), and control (Fig. 1). Therefore, the ant is not effective in controlling the mature larvae of the pine caterpillar moth.

On the other hand, the result of the experiment with first to third instar larvae of the moth revealed that the ant was extremely effective in controlling the younger larvae. In the cases of treatments $A$ and $B$ in which the ants were acting, the mortality attained $100 \%$ within only four days after

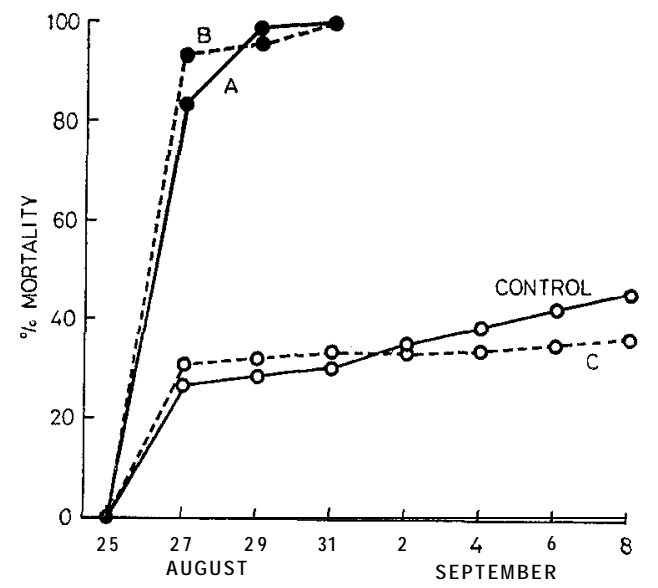

Fig. 2. The mortality of first to third instar larvae of D. spectabilis in an experiment of predation of $F$. yessensis. Treatments and control are the same as in Fig. 1. 
treatments, whereas the mortality attained only $36.7 \%$ in treatment $\mathrm{C}$, and $46.0 \%$ in control even 14 days after treatments (Fig. 2).

\section{DISCUSSION}

Few records have been published on the food of $F$. yessensis. Teranishi (1916) cited a letter from Mr. S. Yamamura who had observed dead scarabaeids in nests of the ant in Korea. Morisita (1940) stated the ant attacked grasshoppers and other insects in Mt. Norikura, Nagano Prefecture, Japan. Higashi (1974) recorded that many workers of the ant collected the honeydew of aphids on the leaves of oak trees in summer and autumn in Ishikari Shore, Hokkaido, Japan. He also observed the ants were hunting live or dead insects and earthworms (Higashi, 1974).

The prey insects given in Table 1 are only a small part of diets of the ant in Korea, but the list suggests $F$. yessensis is a polyphagous predator having a tremendous wide food range. Thus, such a polyphagous behaviour of the ant means that the ant hunts not only harmful insects but also beneficial ones. Therefore, it is a problem that $F$. yessensis may play a beneficial role as a natural enemy of harmful pests such as the pine caterpillar moth, but play an injurious role as well.

In addition to this the ant may protect aphids particularly C. piniformosana. Müller (1958) stated that aphid population was often ten times higher near ant nests than in areas out of range of nests. The amount of honeydew carried into a nest by $F$. polyctena (=F. rufa rufopratensis minor Gösswald) was estimated to be $290-320 \mathrm{~kg}$, and by $F$. rufa (=F. rufarufopratensis major Gosswald) 450-500 kg per year (Zoebelein, 1956). It would seem evident that loss of such quantities of assimilates must have an influence on tree growth (Adlung, 1966). The controversy about the potential usefulness against forest pests of red wood ants among European entomologists is based upon these problems (Adlung, 1966; Finnegan, 1974). The authors will discuss the problem later.

Various ants have been recorded to attack the pine caterpillar at the first larval stage, particularly newly hatched young larvae or larvae moving on twigs. Hirose (1963) observed two species of ants, Crematogaster laboriosa Smith and Iridomyrmex glaber (Mayr) (=I. itoi Forel) attacked larvae of the pine caterpillar moth just hatched from eggs in pine stands in a shore in Fukuoka Prefecture and a mountain in Kumamoto Prefecture, Kyushu. Furuta (1968) also observed in a red pine stand in Kyoto Prefecture that I. glaber and Tetramorium caespitum (Linnaeus) aggregated to surroundings of large egg masses of the moth and preyed larvae just hatched from them. He pointed out this predation was one of the most important mortality factors in the first larval stage of the moth. Kokubo (1971) studied mortality factors of the pine caterpillar moth in the suburbs of Chiba City and reported that larvae just hatched from eggs dropped easily onto the ground by such physical factors as rain and wind, and that most of these larvae died of starvation or predation by ants. Kobayashi and Kuroda (1972) observed in pine stands in Saitama Prefecture that Monomorium nipponense Wheeler, Pristomymex pungens Mayr, Crematogaster 
matsumurai Forel, Lasius niger (Linnaeus) and Formica japonica Motschulsky attacked larvae hatching from eggs of the pine caterpillar moth as well as the first instar larvae moving on twigs. Matsui and Kokubo (1974) observed egg masses of the pine caterpillar moth attacked by ants in a pine stand in Tanashi, Tokyo Prefecture and reported that $L$. niger and $F$. japonica aggregated to the egg masses of the moth and preyed hatching larvae and those moving to needles.

Thus, the pine caterpillar moth is attacked by various ants only in the first instar larval stage. In the experiments of predation by $F$. yessensis presented here, it was concluded that the ant was extremely effective in controlling the first to third instar larvae, though it was not effective against the post-hibernating mature larvae. Younger larvae of the pine caterpillar moth on twigs or needles drop easily to the ground by a slight stimulus such as of contact with ants or of rain, wind and other physical factors. Almost of the dropped larvae are hunted by $F$. yessensis.

As mentioned before, an active controversy has existed for many years among European entomologists on the value of the red wood ants for the purpose of forest pest control. Here the authors will discuss the value of $F$. yessensis as a biological control agent of the pine caterpillar moth in Korean forests as a conclusion of the serial studies.

DeBach and Bartlett (1964) discussed various methods for evaluating the effectiveness of natural enemies and concluded that the experimental method was the most adequate for the precise determination of the importance of natural enemies in regulation of an insect's average population density. The physical check method or the mechanical exclusion technique is one of the experimental method of evaluation. The senior author employed the technique to examine the effect of predation by $F$. yessensis and has concluded the ant was extremely effective in controlling the younger larvae of the pine caterpillar moth in Korea.

As pointed out by DeBach and Bartlett (1964), the cage-exclusion method, however, may have limitations either the applicability to larger and highly motile hosts or an influence on factors other than natural enemies, because the cage may limit the dispersal of the hosts and modify the microclimate. Therefore, the method employed in the present study may not give an accurate measure of the efficacy of $F$. yessensis. It is ideal to evaluate the effect of natural enemies by investigating population dynamics of the pests and the role of natural enemies under natural conditions.

Kokubo (1965) studied the population fluctuations and natural mortality factors of the pine caterpillar moth from 1950 to 1963 in Kashima district of Ibaraki Prefecture where outbreaks occurred in the summer generation of 1950, 1955 and 1961 (In this district the moth has two generations per year). The main reason for the outbreak seemed to be high survival rate of the young larvae in summer. He concluded the climate in July had strong influence upon the survival of the young larvae. He also stated that the effect of natural enemies was usually the greatest on the egg population in both generations and that much greater number of immature stages in the over- 
wintering generation was destroyed by parasitoids and diseases than in the summer generation. Then he concluded that a rapid increase of the moth populations in autumn was considered to be caused by a combined effect of climatic conditions and of natural enemies.

In Korea, Kim (C. W.) and Hyun (1965), Kim (C. W.) et al. (1966) and Hyun (1968) studied the population dynamics of the pine caterpillar moth and the important mortality factors affecting the fluctuations of the moth population in Mt. Kwangkyo, Jijidae and Mt. Chilbo, Keyngki-Do from 1964 to 1966. They concluded that (1) the mortality in the egg stage ranged between 19 and $41 \%$, and the parasitization by egg parasitoids, particularly by Trichogramma dendrolimi Matsumura was the most important; (2) the mortality in the early hatched larval stage was 53-78\%, the greatest one throughout the life span; (3) the most important factor of this mortality was the dropping on the ground in August by rain and other physical factors; (4) the mortality of young larvae by rain was caused by a combined effect of rain intensity, temporal coincidence between rain and hatch of the moth eggs, and size of crown of pine trees; (5) the younger larvae within one week after hatch suffered high mortality by rain; (6) the overwintering larvae suffered $0.3-9.1 \%$ mortality, mostly caused by temperature conditions in March to April and the parasitization by Phanomeris spectabilis Matsumura; (7) the larvae after hibernation suffered 0.9-3.2\% mortality, mostly caused by the parasitization of Pimpla disparis Viereck; (8) the pupae suffered 0.01-2.6\% mortality, mostly caused by the parasitization of Brachymeria obscurata Walker ; (9) the generation mortality was 98.66-99.85\%; and (10) the mortality required to maintain the population at a steady state was calculated as $99.66 \%$, the mortality in the newly hatched larval stage was the highest throughout generation, and it was the key factor for the population fluctuations.

These were results of the population studies investigated in pine stands not inhabited by $F$. yessensis. However, both studies have a common feature; i.e. the mortality in the young larval stages, particularly in the newly hatched larvae is the most important factor for the population fluctuation of the pine caterpillar moth. Kokubo (1965) stated the climate in July had an important effect on the survival of the young larvae, and Hyun (1968) concluded the rain in August was greatly concerned to the mortality of the young larvae by the dropping on the ground.

It is supposed that the predation by $F$. yessensis may be the most important mortality factor in the young larval stages in the forest inhabited by the ant from the authors' studies. Since climatic conditions are variable annually, the intensities of the mortality by the climatic factors may be also variable year by year. In the pine forests inhabited by $F$. yessensis, on the other hand, it is expected that the population density of the pine caterpillar moth may be controlled continuously with a consistent mortality by the predation of $F$. yessensis. This may be supported by the empirical observations that injury by the moth was extremely low in a pine stand inhabited by the ant even in the year the outbreak of the moth was observed in neighboring stand not inhabited by the ant. Further investigations should be conducted for several years by more 
precise comparative studies between forests inhabited and not inhabited by the ant for evaluating quantitatively the effectiveness of the ant as a biolog ical control agent.

There is a belief among biological control workers that the best possibilities of achieving the greatest degree of control are by using monophagous (specific) parasitoids or predators. However, if the host population is periodically depressed by other factors, a specific natural enemy will suffer most, whereas a more general feeder will maintain itself on other hosts during adverse periods (Doutt and DeBach, 1964). It8 and Miyashita (1968) studied on the population dynamics of the fall webworm, Hyphantria cunea Drury in the urban area of Tokyo, and concluded that the population of $\mathbf{H}$. cunea were mainly controlled by polyphagous predators and parasitoids. They suggested that a factor which prevented this species for entering the forest zone in Japan might be predation by birds and other polyphagous predators. Ehler and van den Bosch (1974) stated that polyphagous predators such as Chrysopa carnea Stephens, Orius tristicolor (White) and other bugs were largely responsible for maintaining the cabbage looper, Trichoplusiani (Hübner) population density at innocuous levels on cotton in California and that the mortality caused by these generalists could be density independent and the agents could be said to a poorer regulator but a better control factor. Thus, some polyphagous predators have an ability to maintain the prey population at a low level, since the act of generalists was less affected by decrease of the prey density and at shortage of a food they can maintain their population by hunting other kinds of prey.

F. yessensis has evolved as a polyphagous predator having a tremendous broad spectrum of food range. Such polyphagous habit of the ant may be an important attribute by which the density of the pine caterpillar moth could be consistently maintained at a low level.

Finnegan (1974) emphasized several outstanding qualities possessed by predaceous red wood ants, which were not commonly found among other predators of forest pests. Most of the attributes are true in the case of F. yessen. sis in the pine forests in Korea. F. yessensis can attain a very high population density, requiring a large and continuous supply of food. It is not dependent on a specific prey, but vary its diet according to the prey available. When live prey becomes in short supply, it can divert its attention to honeydew secreted by the pine lachnid aphid, C. piniformosana, and thereby maintain its full nest population. As a result there may be little or not numerical lag behind an increasing pest population. The hunting ground of F. yessensis covers all levels of the forest ranging from the forest floor to the uppermost branches of the crowns. The period of activity is very long, approximately two hundred days from mid April to November in Jinju district. The ant is polygynous and forms colonial nests. Only difference from the more desirable attributes emphasized by Finnegan (1974) is that F. yessensis does limit its predation to the young larval stage of the moth.

Adlung (1966) reviewed detrimental effects of the red wood ants in Europe on beneficial insects and protection of aphids by them. Gösswald (1951) point- 
ed out, however, that the effect of aphids particularly on conifers should be of no great concern to foresters, for the damage was minimal and did not affect plant growth to any marked extent. Bruns (1954) stated that by specializing to hunt the abundant insect, usually pest, there were much fewer beneficial insects captured by red wood ants during infestations. Furthermore, Finnegan (1974) did not deny some of the detrimental effects of red wood ants, but claimed that by and large the accusations had been shown to be insignificant. He pointed out that much of the early criticism probably had resulted from insufficient information on the various species involved in the F. rufa group. Following their proper taxonomic separation, it was found that some species were indeed poor predators, while others were very effective (Finnegan, 1974).

Based upon the fact observed in Korean pine forests, the aphid, C. piniformosana is considered not to be injurious to the adult trees in spite of that the aphids were visited intensively and protected against natural enemies by the ants. Instead, honeydew secreted by the aphid serves as a useful supplementary food when prey insects are in short supply.

Red wood ants are known to be useful not only because a predator of forest pests but also because they affect the forest in several other ways. For example, their excavations aerate the soil in the environs of their nests. The soil is enriched by organic substances that are carried underground. As a result trees are extremely viable and make rapid growth in the environs of ant colonies (Adlung, 1966). Ants also play an important role in transporting sub-soil to the surface, which increase the cation exchange and water-holding capacities of the soil to a considerable extent (Finnegan, 1974). Ants transport seeds of many trees, shrubs and weeds as food and nest building material. The transportation of seeds aids greatly in the distribution and establishment of many kinds of plants. The increase in plants leads an increase in the variety and number of animals, particularly birds (Finnegan, 1974). The seed transport and plant establishment are of special importance in areas where the soil is subject to active erosion (Gosswald, 1951; Adlung, 1966). In Korea $F$. yessensis plays similar roles in silvicultural effects in pine forests. Therefore, it is desirable that the ant colonies should be preserved. It is also advisable to transplant artificially the ant nests to forests not inhabited by the ant. As mentioned in the previous paper (Kim and Murakami, 1981 b), the transplantation of red wood ants has been tested in Europe (Gösswald, 1951). F. lugubris has been successfully transplanted from northern Italy to the Apennines and the Island of Sardinia (Adlung, 1966), and also introduced into Quebec, Canada in 1971 and 1973 (Finnegan, 1975). In Quebec the ant was well established, and it has been demonstrated that the ant has the capacity to hunt large number of the spruce budworm, Choristoneura fumiferana Clem. larvae (McNeil et al., 1978).

Although F. yessensis distributes throughout Korea except Jeju-Do uninvestigated (Kim and Murakami, 1980 a), red pine forests inhabited by the ant are confined in relatively small proportion. From results of the transplantation experiments of F. yessensis colonies, it has been concluded that it may be pos. 
sible to establish the ant colonies by artificial colonization into forests where the environmental conditions are similar with those in forests naturally inhabited by the ant (Kim and Murakami, 1981 b). The colonization should be made from May to July when the active nests increase in number by budding (Kim and Murakami, 1981 a). Thousands of worker ants and several mated queens should be collected from mounds of nests with nest material in forests inhabited by the ant, then transplanted to red pine forests not inhabited. It is recommended also that the environmental conditions of the forests are modified to a certain degree so as to facilitate the establishment if the forests may not be suitable for colonizing nests. For example, when the red pine stand is not suitable because the density of pine trees is so high that sunlight is insufficient to the forest floor, it may be recommended to admit sunlight by thinning out the forest. It may be promising to utilize $F$. yessensis actively for the protection of the red pine forests against $D$. spectabilis by preservation and transplantation of nests including manipulation of environment to favour the ant.

\section{ACKNOWLEDGEMENTS}

The authors wish to thank Professor $Y$. Hirashima for his constant guidance. Thanks are also due to Dr. R. J. Finnegan of Laurentian Forest Research Centre, Canada for his kindness in reading the manuscript presented at the XVI International Congress of Entomology which includes the present paper, and giving helpful suggestions. The authors also thank Dr. Karl Gösswald, Germany and Dr. Mario Pavan, Italy for their suggestions and encouragements since 1970. Finally, the senior author thanks Dr. Tae Gyu Yoon, the ex-President of Gyeongsang National University, for his help promoting the present study and encouragement.

\section{REFEREN CES}

Adlung, K. G. 1966 A critical evaluation of the European research on use of red wood ants (Formica rufa group) for the protection of forests against harmful insects. $Z$. ang.Ent., 57: 167-189

Bruns, H. 1954 Beeinflussung der Kokondichte einer Population der kleinenFichtenblattwespe (Lygaeonematus abietum) durch die rote Waldameise (Formica rufa). Nachrichtenbl. Dtsch. Pflanzenschutz., 6: 33-35

DeBach, P. and B. R. Bartlett 1964 Methods of colonization, recovery and evaluation. In "Biological Control of Insect Pests and Weeds", ed. by P. DeBach, Chapman \& Hall, Ltd., London and Beccles, pp. 402-426

Doutt, R. L. and P. DeBach 1964 Some biological control concepts and questions. In "Biological Control of Insect Pests and Weeds", ed. by P. DeBach, Chapman \& Hall, Ltd., London and Beccles, pp. 118-142

Ehler, L. E. and R. van den Bosch 1974 An analysis of the natural biological control of Trichoplusia ni (Lepidoptera: Noctuidae) on cotton in California. Canad. Ent., 106: 10671073

Finnegan, R. J. 1974 Ants as predators of forest pests. Entomophaga, Mém. H. S., 7: 5359

Finnegan, R. J. 1975 Introduction of a predacious red wood ant, Formica lugubris(Hymen- 
optera: Formicidae), from Italy to eastern Canada. Canad.Ent., 107: 1271-12'71

Furuta, K. 1968 The relationship between population density and mortality in the range of latency of Dendrolimus spectabilis Butler. Jap. J. appl. Ent. Zool., 12: 129-136 (In Japanese with English summary)

Gösswald, K. 1951 D i e $R$ ote Waldameise im Dienste der Waldhygiene. Met a Kinau Verlag, Lüneburg

Higashi, S. 1974 Worker polyethism related with body size in a polydomous red wood ant, Formica (Formica) yessensis Forel.J. Fac. Sci., Hokkaido Univ., Ser. VI, Zool., 19: 695-705

Hirose, Y. 1963 Ants as predators of the hatching larvae of the pine moth, Dendrolimus spectabilis Butler. Proc. Assoc. Pl. Prot. Kyushu, 9: 86-89 (In Japanese with English summary)

Hyun, J. S. 1968 Studies on the major mortality factors of the pine moth, Dendrolimus spectabilis and their effects on the population fluctuations. Kor. J. PI. Prot., 1: 1-24 (In Korean with English summary)

Itô, Y. and K. Miyashita 1968 Biology of Hyphantria cunea Drury (Lepidoptera: Arctiidae) in Japan V. Preliminary life tables and mortality data in urban areas. Res. Popul. Ecol., 10: 177-209

Kim, C. H. and Y. Murakami 1980 a Ecological studies on Formica yessensis Forel, with special reference to its effectiveness as a biological control agent of the pine caterpillar moth in Korea I. Geographical and ecological distributious of Formica yessensis Fore1 (Hymenoptera: Formicidae). J.Fac.Agr., Kyushu Univ., 24: 239-245

Kim, C. H. and Y. Murakami 1980 b Ecological studies on Formica yessensis Forel, with special reference to its effectiveness as a biological control agent of the pine caterpillar moth in Korea II. Bionomics of Formica yessensis Fore1 (Hymenoptera:Formicidae). J. Fac. Agr., Kyushu Univ., 25: 119-133

Kim, C. H. and Y. Murakami 1981 a Ecological studies on Formica yessensis Forel, with special reference to its effectiveness as a biological control agent of the pine caterpillar moth in Korea III. Nest distribution and environmental conditions of nest sites. J. Fac. Agr., Kyushu Univ., 26: 9-19

Kim, C. H. and Y. Murakami 1981 b Ecological studies on Formica yessensis Forel, with special reference to its effectiveness as a biological control agent of the pine caterpillar moth in Korea IV. Artificial colonization of nests. J. Fac. Agr., Kyushu Univ., 26: $39-44$

Kim, C. W. and J. S. Hyun 1965 Research and survey of the control of pine moth, Dendrolimus spectabilis Butler. Ent. Res. Bull., Ent. Inst. Korea Univ., 1: 5-113

Kim, C. W., J. S. Hyun and T. Y. Lee 1966 Research and survey of the control of pinc moth, Dendrolimus spectabilis Butler (II). Ent. Res. Bull., Ent. Inst. Korea Univ., 2: 5-67

Kobayashi, K. and T. Kuroda 1972 Predators which attacked newly hatched larvae of Dendrolimus spectabilis. Trans. 83rd Meeting Jap. For. Soc.:267-269 (In Japanese)

Kokubo, A. 1965 Population fluctuations and natural mortalities of the pine-moth, Dendrolimus spectabilis. Res. Popul. Ecol., 7 :23-34

Kokubo, A. 1971 Mortality factors of the pine-moth, Dendrolimus spectabilis Butler in the suburbs of Chiba City. Jap. J. appl. Ent. Zool., 15: 203-210 (In Japanese with English summary)

Matsui, H. and A. Kokubo 1974 Observations on egg masses of the pine-moth, Dendrolimus spectabilis Butler attacked by ants. J. Jap. For. Soc., 56: 182-184 (In Japanese)

McNeil, J. N., J. Delisle and R. J. Finnegan 1978 Seasonal predatory activity of the introduced red wood ant, Formica lugubris (Hymenoptera : Formicidae) at Valcartier, Quebec, in 1976. Canad.Ent., 110: 85-90.

Morisita, M. 1940 Red wood ants in Mt. Norikura. Yamugoya, 106: 53-59 (Republished in Morisita, M. 1979 Synthesis of Dr. M. Morisita's Papers in Ecology, Vol. I, Shisakusha, 
Tokyo, pp. 65-71) (In Japanese)

Mäller, H. 1958 Zur Kenntnis der Schäden, die Lachniden an ihren Wirtsbäumenhervorrufen können. Z. ang. Ent., 42: 284-291

Teranishi, C. 1916 Yesso red wood ant and late Mr. Yamamura. Insect World, 20: 118-119 (In Japanese)

Wellenstein, G. 1952 Zur Ernährungsbiologie der roten Waldameise (Formica rufa L.). Z. Pflanzenkr., 59: 430-451

Zoebelein, G. 1956 Der Honigtau als Nahrung der Insekten. Z. ang. Ent., 38: 369-416; 39: 129-167 